\title{
APLIKASI ADMINISTRASI ONLINE BERBASIS ANDROID MENGGUNAKAN GOOGLE APPS SEBAGAI SARANA PELAYANAN MASYARAKAT DITENGAH PANDEMI COVID19
}

\author{
Dadan Zaliluddin \\ Jurusan Informatika, Fakultas Teknik Universitas Majalengka \\ Jln. KH. Abdul halim No. 103 Majalengka \\ dadanzuu@gmail.com
}

\begin{abstract}
Abstrak - Pandemi Covid 19 upaya untuk mencegah penyebaran virus corona termasuk pembatasan perjalanan, karantina, pemberlakuan jam malam, penundaan dan pembatalan acara, serta penutupan fasilitas. Berbagai penutupan perbatasan negara atau pembatasan penumpang yang masuk, penapisan di bandara dan stasiun kereta, serta informasi perjalanan mengenai daerah dengan transmisi lokal. Dalam hal pelayanan adnimistrasi Desa dalam keadaan normal tidak dapat dihindari kontak fisik untuk penyelesaian administrasi untuk itu peranan teknologi informasi dalam suatu instansi sangat dibutuhkan karena teknologi sudah sangat berkembang di jaman sekarang. Hal ini dapat mengurangi kontak fisik namun penyelesaian administrasi tetap berjalan lancar, kemajuan ilmu dan teknologi yang menunjang secara komputerisasi yang penting dalam membantu kegiatan kerja sehari-hari. Hampir disegala bidang membutuhkan komputer sebagai alat bantu, karena memiliki kelebihan yaitu dari segi ketelitian dan segi performa dalam pengolahan data.t ak hanya itu, Mobile Application juga memiliki layanan seperti pemrosesan bahasa, kecerdasan buatan, dan program-program standar di pekerjaan. Pokoknya layanan yang tidak memerlukan Anda untuk secara fisik berada di depan perangkat keras seperti komputer dan laptop. Desa merupakan suatu organisasi dan sebagai bagian terkecil dari sistem pemerintahan administratif di Indonesia, dituntut untuk dapat mengikuti perkembangan teknologi dan terus meningkatkan kemampuannya didalam mengelola data administrasi kependudukan desa.
\end{abstract}

Kata kunci - Desa, Administrasi, Covid-19, Mobile Aplication, Android.

\section{PENDAHULUAN}

Pada masa pandemu Covid-19 upaya untuk mencegah penyebaran virus corona termasuk pembatasan perjalanan, karantina, pemberlakuan jam malam, penundaan dan pembatalan acara, serta penutupan fasilitas. Berbagai penutupan perbatasan negara atau pembatasan penumpang yang masuk, penapisan di bandara dan stasiun kereta, serta informasi perjalanan mengenai daerah dengan transmisi lokal.

Dalam hal pelayanan adnimistrasi Desa dalam keadaan normal tidak dapat dihindari kontak fisik untuk penyelesaian administrasi untuk itu peranan teknologi informasi dalam suatu instansi sangat dibutuhkan karena teknologi sudah sangat berkembang di jaman sekarang. Hal ini dapat mengurangi kontak fisik namun penyelesaian administrasi tetap berjalan lancar, kemajuan ilmu dan teknologi yang menunjang secara komputerisasi yang penting dalam membantu kegiatan kerja sehari-hari. Hampir disegala bidang membutuhkan komputer sebagai alat bantu, karena memiliki kelebihan yaitu dari segi ketelitian dan segi performa dalam pengolahan data.

Tak hanya itu, Mobile Application juga memiliki layanan seperti pemrosesan bahasa, kecerdasan buatan, dan programprogram standar di pekerjaan. Pokoknya layanan yang tidak memerlukan Anda untuk secara fisik berada di depan perangkat keras seperti komputer dan laptop

Pemerintah Desa yang di dalamnya terdapat administrasi salah satunya adalah Desa Tegalsari Kecamatan Maja, dimana sistem administrasinya melibatkan banyak masyarakat yang memerlukan pelayanan admministrasi yang baik. Terdapat beberapa pelayanan administrasi kependudukan yang dilayani oleh pemerintah Desa Tegalsari Kecamatan Maja diantaranya 
administrasi keterangan tinggal,surat menyurat untuk pengantar dll.

Berdasarkan latar belakang tersebut penulis melakukan penelitian secarang langsung di Desa Tegalsari Kecamatan Maja untuk menganalisis dan merancang suatu sistem pengolahan data berbasis Android.

\section{Metodologi Penelitian}

\section{A. Metodologi SDLC air terjun (waterfall)}

Menurut (Rosa A.S M.Shlahuddin, 2013:28), model SDLC air terjun (waterfall) sering disebut juga model sekuensial linier (sequential linear) atau jalur hidup klasik (classic life cycle). Model air terjun menyediakan pendekatan alur hidup perangkat lunak secara sekuensial atau terurut dimulai dari analisis, desain, pengodean, pengujian, dan tahap pendukung (support). Berikut adalah gambar model air terjun :

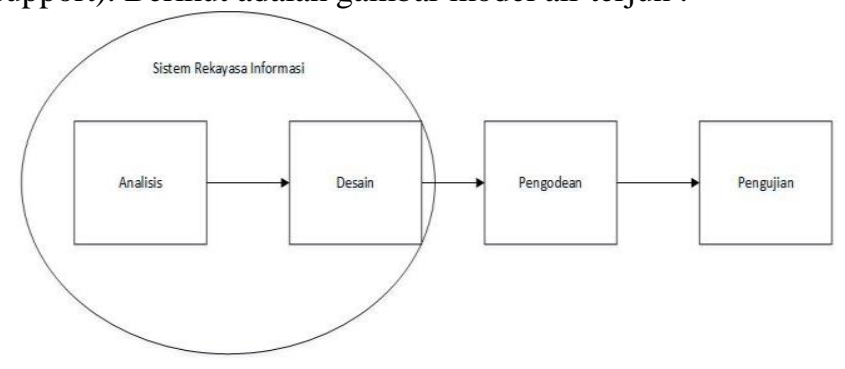

Gambar 1. Ilustrasi Model Waterfall

\section{B. Could Computing}

Mobile Application merupakan istilah dari bahasa Inggris yang berarti komputasi awan. Untuk istilah 'awan' merupakan metafora dari internet. Jadi, definisi yang sebenarnya dari Mobile Application adalah sebuah proses pengolahan sistem daya komputasi, melalui jaringan internet yang menghubungkan antara satu perangkat komputer dengan komputer lain, dalam waktu yang sama. Sehingga, komputasi awan sendiri juga termasuk dalam teknologi yang menjadikan internet sebagai center of server untuk mengelola data pengguna (user). Dengan menggunakan Mobile Application, maka anda tidak perlu menginstall sebuah aplikasi secara manual, dan memudahkan dalam mengakses informasi melalui internet
This is your sample text here. Enter your text here

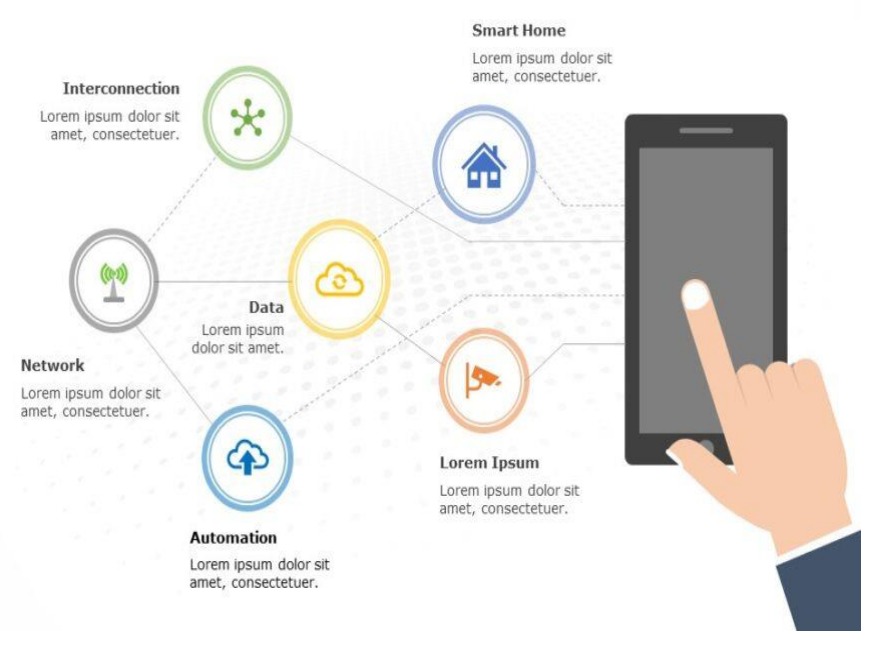

Gambar 2. Ilustrasi Mobile Application

Mobile Application terbilang layanan yang relatif baru, tapi sudah digunakan oleh beragam perusahaan mulai dari yang kecil hingga korporasi besar, perusahaan atau kementerian pemerintah, bahkan pengguna individu.

Tak hanya itu, Mobile Application juga memiliki layanan seperti pemrosesan bahasa, kecerdasan buatan, dan program-program standar di pekerjaan. Pokoknya layanan yang tidak memerlukan Anda untuk secara fisik berada di depan perangkat keras seperti komputer dan laptop.

Cara kerja Mobile Application

Setiap varian Mobile Application memiliki dua faktor yang sama secara umum, yakni data center yang berada di luar dan harus memiliki internet untuk mengaksesnya. Sumber daya server dalam data center ini dikumpulkan untuk membuat platform yang sangat besar agar siap menampung layanan virtual.

Sumber daya yang dikumpulkan ini diatur agar bisa fleksibel, sehingga para penggunanya bisa mengakses lebih banyak ruang penyimpanan jika diperlukan. Demikian pula dengan sumber daya yang sedang tidak digunakan, ini akan dilepas kembali ke cloud jika memang sudah tidak lagi dibutuhkan.

Penggunaan sumber daya berbasis on-demand ini menawarkan skalabilitas dan fleksibilitas yang hampir tidak terbatas. Pasalnya, kebutuhan Anda akan Mobile Application senantiasa berubah atau dinamis.

Keuntungan menggunakan Mobile Application

Mobile Application bukan sekadar bisa mengakses file secara remote. Berkat Mobile Application, penggunanya dapat mengecek email di komputer mana pun, atau bahkan 
menyimpan serta mengakses file dari mana pun seperti Dropbox atau Google Drive.

Maka itu, perusahaan-perusahaan yang menggunakan cloud dapat memangkas biaya secara signifikan. Sebelum adanya cloud, perusahaan harus membeli, memiliki, membangun manajemen informasi teknologi (IT) mereka sendiri. Sebaliknya, dengan adanya cloud, perusahaan hanya membutuhkan pusat server dan divisi IT agar memastikan internet yang dimiliki cepat dan stabil, agar karyawannya bisa berinteraksi dengan cloud secara online.

Cloud membuat para karyawan bisa menghemat ruang penyimpanan di laptop atau komputer. Saat ada perangkat lunak atau program yang membutuhkan update, tinggal download saja tanpa menggunakan cara tradisional seperti menggunakan disc atau flash drive.

Contohnya Adobe, penggunanya bisa mengakses aplikasi melalui Cretive Cloud dengan model subscription. Ini memungkinkan penggunanya mengunduh versi terbaru dan memperbaiki program lebih mudah.

Perusahaan ICT besar telah membelanjakan miliaran dollar sejak tahun 1990-an untuk mengembangkan Mobile Application. Sebagai contoh, Sun's telah dikenal dengan slogan "ther network is the computer" di dirikan pada akhir tahun 1980-an.Salesforce.com telah menyediakan on-demand Software as a Service (SaaS) untuk pelanggannya sejak 1999. IBM dan Microsoft telah memulai layanan Web sejak awal tahun 2000-an. Microsoft's Azure menyediakan layanan sistem operasi dan satu set tools dan layanan. Google's pepuler dengan Google Docs menyediakan Web-based pengolah kata, spreadsheet dan apliasi presentasi. Google App menperkenankan pengembang sistem untuk menjalankan aplikasi Phyton/Java di dalam infrastruktur Google. Amazaon dikenal sebagai penyedia layanan Web seperti ECS (Elastic Compute Cloud) dan S3 (Simple Storage Service). Yahoo! mengumumkan bahwa dapat menggunakan framework Apache Hadoop untuk memperkenakan pengguna bekerja dengan ribuan nodes dan 1 petabyte (1 miliar gygabytes) data.[2]

\section{HASIL DAN PEMBAHASAN}

Dalam penelitian memiliki beberapa target capaian yang akan dilakukan pada tahap berikutnya, diantaranya seperti tertera pada gambar 2

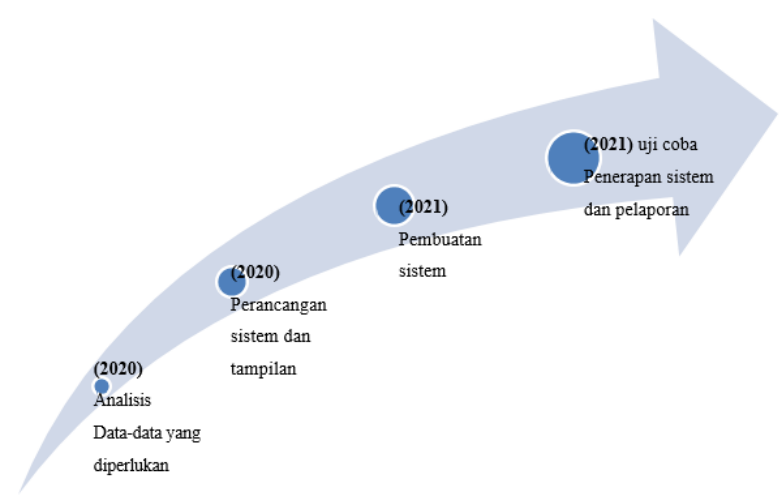

Gambar 2. Road Map Penelitian

Pada tahun 2020 dilakukan dilakukan analisis data-data yang diperlukan serta template surat-surat sesuai aturan administrasi, pada tahun ini juga dibuat peracangan sistem dan tampilan sesuai analisis yang dilakukan

Pada tahun 2021, dari hasil perancangan sistem mulai dibuat serta diuji sesuai kecocokan dengan lingkungan di Desa pada tahun ini juga mulai diterapkan dan disosialisasikan kepada masyarakat

Implementasi sistem ini berisi tentang dokumentasi sistem yang meliputi tampilan layar sistem dan hasil pencetakkan dari sistem.
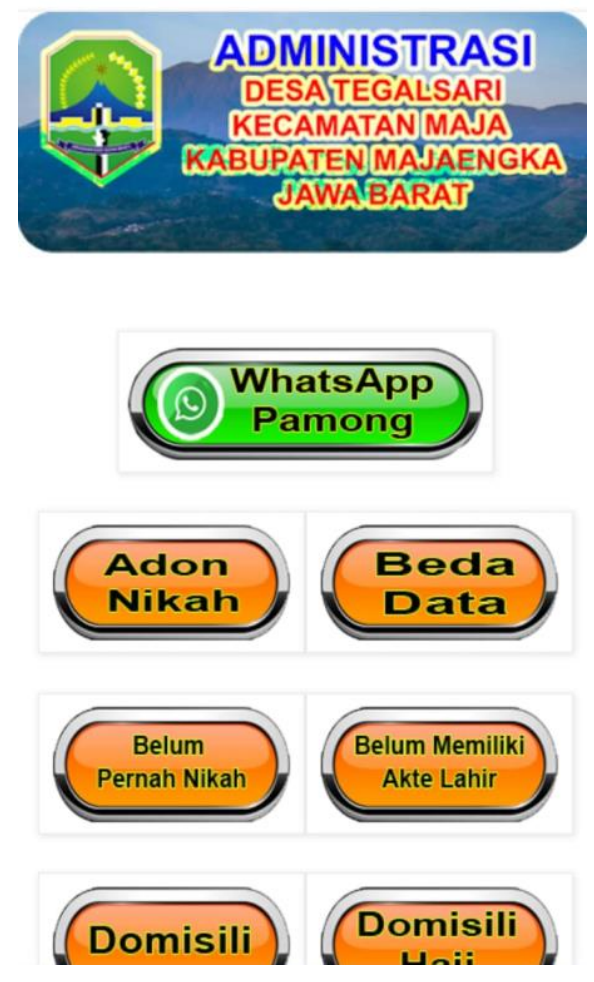

Gambar 2. Menu Tampilan Awal untuk penduduk 
Contoh Tampilan input data untuk penduduk

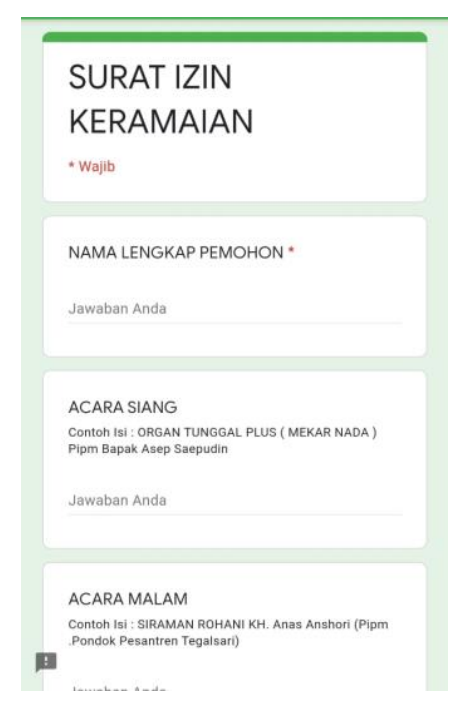

Gambar 3. Contoh tampilan input data untuk penduduk

Tampilan Menu untuk Desa

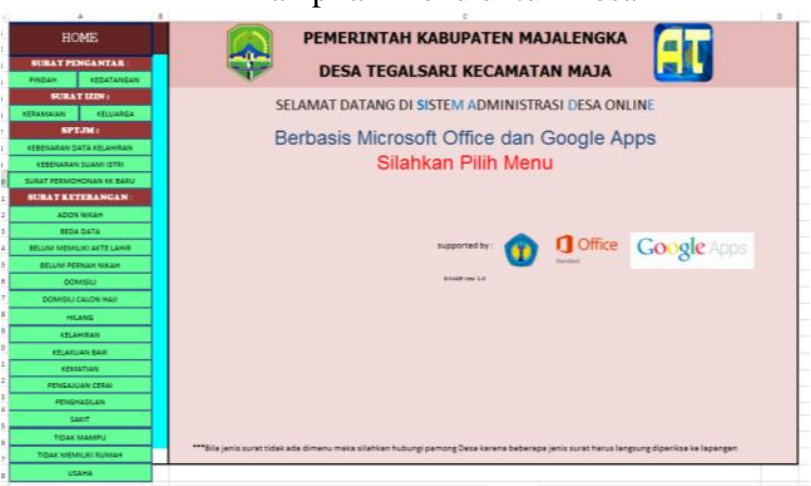

Gambar 4. Menu Tampilan Menu untuk Desa

\section{KESIMPULAN}

Dari uraian diatas maka bisa ditarik kesimpulan Sistem informasi berbasis Android dapat meminimalisir penularan covid-19 dikarenakan bisa mengurangi kotak fisik ketika menyelesaikan pelayanan administrasi, dengan sistem ini dimasalah pelayanan adminitrasi yang sedang dihadapi pada saat pandemi dan sebelum pandemi dapat diselesaikan dan dipermudah baik dari sisi proses pelayanan atau proses birokrasi serta sistem android dapat memberikan keamanan data dan kemudahan dalam pembuatan surat-surat untuk warga desa
Dan saya mengucapkan terima kasih kepada pihak terkait akan jalanya aplikasi ini sehingga bisa diterapkan dan dapatber manfaat bagi warga masyarakat yang membutuhkan solusi ditengah pandemi ini semoga kedepanya penerapan dan upgrage sistem dapat diterapkan dengan sistem yang lebih baik.

\section{UCAPAN TERIMA KASIH}

Terima kasih kami ucapkan semua pihak yang telah memberikan kesempatan kepada kami untuk melakukan riset, dan juga kepada stakeholder tidak dapat kami sebutkan satu persatu sehingga tulisan ini dapat diselesaikan.

\section{REFERENSI}

[1] A.S. Rosa, M. Shalahuddin. 2011. Modul Pembelajaran Rekayasa Perangkat Lunak (Terstruktur dan Berorientasi Objek). Bandung : Modula

[2] Al Fatta, Hanif, 2007, Analisis dan Perancangan Sistem Informasi untuk Keunggulan Bersaing Perusahaan \& Organisasi Modern, ANDI, Yogyakarta.

[3] Ashari Ahmad, Setiawan Herri ,Mobile Application : Solusi ICT Jurnal Sistem Informasi (JSI) VOL. 3, NO. 2, Oktober 2011.

[4] B, Al - Bahra bin Ladjamuddin. 2004. Konsep Sistem Basis Data dan Implementasinya. Yogyakarta : GRAHA ILMU.

[5] Bahra Al,bin Ladjamudin, 2005, Analisis dan Desain Sistem Informasi, GRAHA ILMU, Yogyakarta.

[6] Dharwiyanti, Sri dan Romi Satria Wahono. 2003. Pengantar Unified Modeling Language(UML). IlmuKomputer.Com

[7] Fatansyah, 2012, Basis Data, INFORMATIKA, Bandung.

[8] Marlinda S.Kom, Linda, Sistem basis data, 2004, ANDI, Yogyakarta.

[9] Nugroho, Adi. 2005. Analisis dan Perancangan Sistem Informasi dengan Metodologi Berorientasi Objek. Bandung : INFORMATIKA.

[10] Pudjo Widodo, Prabowo, Herlawati. 2011. Menggunakan UML. Bandung : INFORMATIKA.

[11] Sommerville, Ian, 2003, Software Engeneering (Rekayasa Perangkat Lunak) jilid 1, Erlangga, Jakarta.

[12] Sommerville, Ian. 2003. Software Engeneering (Rekayasa Perangkat Lunak) jilid 2. Jakarta : Erlangga.

[13] Supardi, Ir. Yuniar. 2012. Semua Bisa Menjadi Programmer Visual Basic 2010. Jakarta : Elex Media Komputindo.

[14] Sutabri, Tata. 2012. Analisis Sistem Informasi. Yogyakarta : ANDI.

[15] Sutabri, Tata. 2012. Konsep Sistem Informasi. Yogyakarta : ANDI

[16] Sutanta, Edhy, 2003, Sistem Informasi Manajemen, GRAHA ILMU, Yogyakarta. Tim Penyusun, 2016, Profil Desa Tegalasari, Talaga Majalengka.

[17] Waljiyanto. 2003. Sistem Basis Data. Yogyakarta : GRAHA ILMU.

[18] Yakub, 2012, Pengantar Sistem Informasi, GRAHA ILMU, Yogyakarta.1997 